\title{
Prevalence of occult hepatitis B virus infection among blood donors in Ouagadougou, Burkina Faso
}

\author{
${ }^{* 1} \mathrm{Ky} / \mathrm{Ba}, \mathrm{A} .,{ }^{2}$ Sanou, M., ${ }^{3}$ Ouédraogo, A. S., ${ }^{2}$ Sourabié, I. B., ${ }^{4} \mathrm{Ky}, \mathrm{A} . \mathrm{Y} .,{ }^{5}$ Sanou, I., \\ ${ }^{2}$ Ouédraogo/Traoré, R., and ${ }^{6}$ Sangaré, L. \\ ${ }^{1}$ Centre Hospitalier Universitaire de Bogodogo, 14 BP 371, Ouagadougou, Burkina Faso \\ ${ }^{2}$ Centre Hospitalier Universitaire Charles De Gaule, Ouagadougou, Burkina Faso \\ ${ }^{3}$ Centre Hospitalier Universitaire Souro Sanou, Bobo-Dioulasso, Burkina Faso \\ ${ }^{4}$ Intrahealth International, Burkina Faso \\ ${ }^{5}$ Centre Hospitalier Universitaire Blaise Compaoré, Ouagadougou, Burkina Faso \\ ${ }^{6}$ Centre Hospitalier Universitaire Yalgado Ouedraogo, Ouagadougou, Burkina Faso \\ *Correspondence to: absetou@yahoo.fr
}

\begin{abstract}
:
Background: In Burkina Faso, the polymerase chain reaction (PCR) assay is not routinely used in the biological qualification of blood donations and this constitutes a risk factor for the transmission of occult hepatitis $B$ virus (HBV) infection during blood transfusion. The objective of this study is to determine the prevalence of occult $B$ infection (OBI) among blood donors for the purposes of improved blood safety in Burkina Faso.

Methodology: A descriptive cross-sectional study of $300 \mathrm{HBsAg}$ negative blood donors was conducted in the city of Ouagadougou, Burkina Faso from April to October 2020. Anti-HBc antibody was determined using the

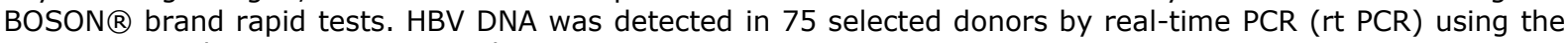
7500 Fast Real Time PCR assay technique.

Results: Of the $300 \mathrm{HBsAg}$ negative donors, 208 (69.3\%) were males while $92(30.7 \%)$ were females, with average age of 30.18 years. Anti-HBc antibody was detected in 39 cases (13\%). Of the 75 donor samples tested by rt PCR, $3(4 \%)$ were positive for HBV DNA (occult B infection); 2 of which were anti-HBC antibody positive (seropositive $\mathrm{OBI}$ ) while 1 was anti-HBc antibody negative (seronegative OBI).

Conclusion: Given the prevalence of OBI of $4 \%$ in this study and its consequences in blood recipients, it appears necessary that in addition to the classic serological markers of hepatitis $B$, to test for the presence of HBV DNA among blood donors in order to improve transfusion safety.
\end{abstract}

Keywords: Prevalence, Occult B infection; Blood donors, Ouagadougou.

Copyright 2021 AJCEM Open Access. This article is licensed and distributed under the terms of the Creative Commons Attrition 4.0 International License <a rel="license" href="http://creativecommons.org/licenses/by/4.0/", which permits unrestricted use, distribution and reproduction in any medium, provided credit is given to the original author(s) and the source. Editor-in-Chief: Prof. S. S. Taiwo

\section{Prévalence de l'infection occulte par le virus de l'hépatite B chez les donneurs de sang à Ouagadougou, Burkina Faso}

\author{
${ }^{* 1} \mathrm{Ky} / \mathrm{Ba}, \mathrm{A} .,{ }^{2}$ Sanou, M., ${ }^{3}$ Ouédraogo, A. S., ${ }^{2}$ Sourabié, I. B., ${ }^{4} \mathrm{Ky}, \mathrm{A} . \mathrm{Y} .,{ }^{5}$ Sanou, I., \\ 2Ouédraogo/Traoré, R., and 'Sangaré, L. \\ ${ }^{1}$ Centre Hospitalier Universitaire de Bogodogo, 14 BP 371, Ouagadougou, Burkina Faso \\ ${ }^{2}$ Centre Hospitalier Universitaire Charles De Gaule, Ouagadougou, Burkina Faso \\ ${ }^{3}$ Centre Hospitalier Universitaire Souro Sanou, Bobo-Dioulasso, Burkina Faso \\ ${ }^{4}$ Intrasanté International, Burkina Faso \\ ${ }^{5}$ Centre Hospitalier Universitaire Blaise Compaoré, Ouagadougou, Burkina Faso \\ ${ }^{6}$ Centre Hospitalier Universitaire Yalgado Ouedraogo, Ouagadougou, Burkina Faso \\ *Correspondance à: absetou@yahoo.fr
}

\section{Résume:}

Contexte: Au Burkina Faso, la polymérase chain réaction (PCR) n'est pas utilisée lors de la qualification biologique des dons et cela constitue un facteur de risque de transmission de I'Infection Occulte du virus B 
(VHB) lors des transfusions sanguines. L'objectif de cette étude était de déterminer la prévalence de l'infection occulte $B$ chez les donneurs de sang en vue d'une meilleure sécurité transfusionnelle.

Méthodologie: Une étude transversale prospective, réalisée d'avril à octobre 2020 dans la ville de Ouagadougou incluant 300 donneurs de sang AgHBs négatif. L'anticorps anti HBc a été déterminé par les tests rapides de marque $B O S O N \otimes$. L'ADN du VHB a été recherché chez 75 donneurs par PCR en temps réel (rt PCR) avec le 7500 Fast Real Time PCR.

Résultats: Parmi les 300 donneurs AgHBs négatifs, $208(69,3 \%)$ étaient des hommes et $92(30,7 \%)$ des femmes. L'âge moyen était de 30,18 ans. La recherche de I'Ac anti-HBc était positive dans 39 cas (13\%). Parmi les 75 échantillons passés à la rt PCR, $3(4 \%)$ étaient positifs pour l'ADN du VHB. Sur les 3 cas d'ADN VHB positifs, $2(66,67 \%)$ étaient positifs Ac anti $\mathrm{HBC}$ et $1(33,33 \%)$ Ac anti HBc négatif.

Conclusion: Compte tenu de la prévalence de l'infection occulte $B$ et ses conséquences chez les donneurs de sang et chez les receveurs, il devient nécessaire de rechercher, en plus des marqueurs sérologiques classiques de I'hépatite $B$, I'ADN VHB pour une meilleure sécurité transfusionnelle.

Mots clés: Prévalence, Infection occulte de I'HBV, Donneurs de sang, Ouagadougou

\section{Introduction:}

Hepatitis B virus (HBV) infection is a global public health challenge. According to the World Health Organization (WHO) in 2017 there were nearly two billion people infected with HBV worldwide, including 360 million chronic carriers who are at risk of cirrhosis and hepatocellular carcinoma (HCC) (1). In Africa, chronic hepatitis is the second leading cause of death after tuberculosis, with more than 60 million people affected. Injection with non-sterile needles and sharps in health facilities, tattoos, scarifications, and to a lesser extent, blood transfusion are the various means of HBV transmission (2). In Burkina Faso, HBV infection is the major cause of hepatic cirrhosis and liver cancer (3). The country is among those with high endemicity, where the carriage of hepatitis B virus surface antigen (HBsAg) is high in the general population, with a prevalence varying from $9 \%$ to $15 \%$ in 2018 (4-7), and seroprevalence rate of $7.28 \%$ among blood donors in 2017 (8).

In some people, there is persistence of HBV DNA in liver tissue and/or serum of individuals in whom the HBsAg is not detectable in the blood, with or without the presence of anti-HBc antibodies (9), which is referred to as occult $B$ infection (OBI). This OBI occurs all over the world, but its frequency is linked to the prevalence of HBV infection in a specific geographical area. Occult HBV infection is transmissible through blood transfusion in the event of biological qualification of donations without the use of the polymerase chain reaction (PCR) assay, and through organ transplants. The prevalence of occult HBV infection in Burkina Faso varies according to studies; Birama et al., (10) reported a prevalence rate of $7.3 \%$ in 2018 in the population of Ouagadougou while Somda et al., (11) reported a seroprevalence rate of $32.8 \%$ among blood donors in 2016 .

The molecular mechanisms underlying the occurrence of OBI are diverse and play an important role in the development of hepatocellular cancer (12). Chronic carriage of hepatitis $\mathrm{C}$ virus (HCV) and human immunodeficiency virus (HIV) are associated with a high prevalence of OBI (13). In Burkina Faso, PCR assay is not used in the biological qualification of donations, and this constitutes a risk factor for transmission of OBI during blood transfusions. It is in order to determine the prevalence of OBI in blood donors in the city of Ouagadougou that this study was carried out, with the aim of ensuring better transfusion safety.

\section{Materials and method:}

\section{Study setting and design}

This was a descriptive cross-sectional study of blood donors declared suitable for blood donation and tested negative for HBsAg in Ouagadougou Regional Blood Transfusion Center of (CRTS/O) and the Pietro Annigoni Biomolecular Research Center (CERBA) from April to October 2020. The CRTS/O served as the site for collecting study samples as well as for testing HBsAg and anti-HBcAb in blood donors. The CERBA served as the site for the detection of HBV DNA by the real-time PCR assay.

\section{Sampling}

All blood donors declared suitable for donation and tested negative for HBsAg were included in this study. A total of 300 randomly selected donors were divided into 6 groups of 50, and one group consisted of samples collected and tested on the same day for anti-HBc antibody. In each group of 50,15 samples were randomly selected for the quantitative detection of HBV DNA, but included all anti-HBc antibody positive samples, with a total of $75 \mathrm{HBsAg}$ negative samples (made of 39 anti-HBc positive and 36 anti-HBc negative samples) as shown in the workflow diagram (Fig 1). 


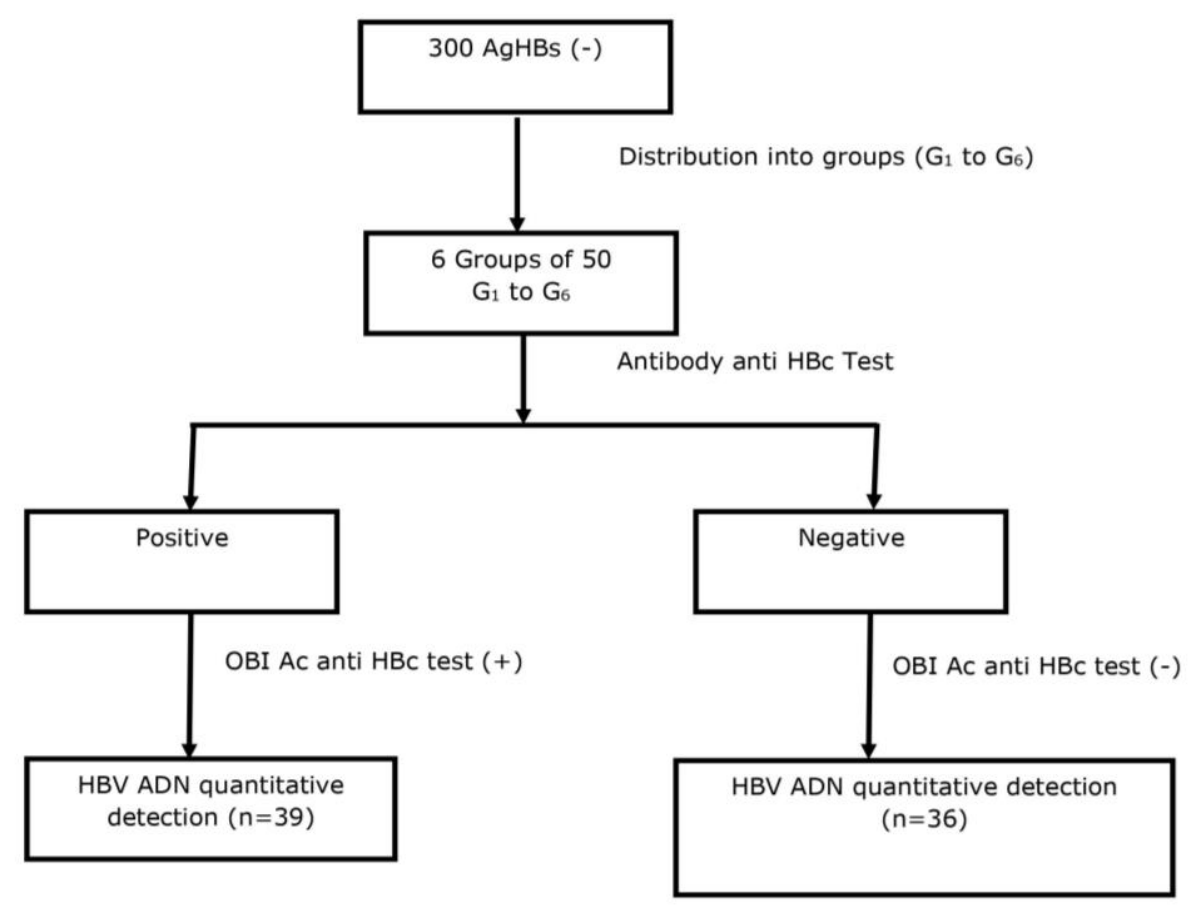

Fig 1: The workflow of the study

\section{Detection of HBsAg and anti-HBc antibody}

The Cobas e 601 automaton was used for the detection of HBsAg at CRTS/O. This test is an immunoassay that uses electrochemiluminescence for the qualitative detection of hepatitis B surface antigen (HBsAg) in human serum and plasma. This automaton has a sensitivity of $99.9 \%$ and a specificity of $100 \%$. The method for the detection of anti$\mathrm{HBC}$ antibody was carried out using the rapid test 1H27C2 HBcAb IgG brand 'Boson'. The sensitivity of this test method is $97.2 \%$ and the specificity is $98.4 \%$.

\section{Detection of HBV DNA by real time PCR}

HBV DNA was extracted from $200 \mu$ l of plasma using the PureLink $\AA$ Genomic DNA Kits (Life Technologies, Van Alleen Way Carlsbad, CA, USA) according to the manufacturer's protocol. This is a column extraction method based on the principle of nucleic acid molecules retention on a silicate membrane (filter). Quantification of HBV DNA was performed on the 7500 Fast Real Time PCR machine, in a reaction volume of $20 \mu$ l containing $10 \mu$ l of oasigTM $2 \times$ qPCR Master Mix, $1 \mu$ l of HBV Primer/Probe mix, $4 \mu$ l of nuclease-free water and $5 \mu$ l of extracted DNA. The amount of viral load in the samples is related to the standard curve obtained by making a cascade dilution to $1 / 10$ of the positive control provided by the manufacturer ( 5 times). The concentration of control was $2 \times 10^{8}$ copies $/ \mathrm{ml}$.

\section{Statistical analysis}

Data were analyzed using EPI INFO version 7.2 software. Chi-square was used to measure association between the variables, and the level of significance ( $p$ value) used was 0.05

\section{Ethical considerations}

The study received approval from the CNTS Internal Scientific Review Committee (CIRS). The anonymity and confidentiality of serological results from blood donors were ensured.

\section{Results:}

A total of $300 \mathrm{HBsAg}$ negative blood donors, including 208 males (69.3\%) and 92 females $(30.7 \%)$ participated in the study. The male to female ratio was 2.3 and the mean age was 30.18 years with a range of 18-58 years. Majority of the donors were in the age groups $20-34(68.0 \%)$ and $35-50$ $(24.3 \%)$ years. Of the 300 donations, 201 were collected at fixed sites and 99 at mobile sites. Table 1 shows the frequency distribution of the donors by age group and gender. The hepatitis $B$ virus anti $\mathrm{HBC}$ antibody was detected in 39 donors representing a prevalence of $13 \%$. Table 2 shows the frequency distribution of anti-HBc antibody with respect to gender and age group of donors.

Of the 75 donors with undetectable HBsAg screened by real time PCR, HBV DNA was detected in 3, representing a rate of $4 \%$. Of the 3 positive samples, $2(2.7 \%)$ were anti $\mathrm{HBC}$ positive (seropositive OBI) and 1 (1.3\%) was anti $\mathrm{HBC}$ antibody negative (seronegative 
OBI). The viral load of samples with HBV DNA varied from $335 \mathrm{IU} / \mathrm{ml}$ - $26454 \mathrm{IU} / \mathrm{ml}$. Table 3 presents the prevalence of OBI with respect to gender and age groups. Table 4 presents the summary of the results of the three OBI cases with respect to the type of donor and the viral load.

Table1: Gender and age group distribution of HBsAg negative blood donors at Ouagadougou Regional Blood Transfusion Center of (CRTS / O), Burkina Faso

\begin{tabular}{lccc}
\hline \multicolumn{2}{c}{ Socio-demographic characteristics } & Number (n) & Percentage (\%) \\
\hline Gender & Male & & 69.3 \\
& Female & 208 & 30.7 \\
Age group (years & $<20$ & 92 & 3.3 \\
& $20-34$ & 10 & 68.0 \\
& $35-50$ & 204 & 24.3 \\
\hline
\end{tabular}

Table 2: Frequency of anti $\mathrm{HBC}$ antibodies with respect to gender and age group of $\mathrm{HBsAg}$ negative blood donors at Ouagadougou Regional Blood Transfusion Center of (CRTS / O), Burkina Faso

\begin{tabular}{|c|c|c|c|c|}
\hline $\begin{array}{c}\text { Socio- } \\
\text { demographic } \\
\text { characteristics }\end{array}$ & $\begin{array}{c}\text { Anti-HBc negative } \\
\text { n ( } \%)\end{array}$ & $\begin{array}{c}\text { Anti-HBc positive } \\
\text { n }(\%)\end{array}$ & $\overline{X^{2}}$ & $p$ value \\
\hline \multicolumn{5}{|l|}{ Gender } \\
\hline Male & $178(85.6)$ & $30(14.4)$ & 1.2145 & $0.2705^{*}$ \\
\hline Female & $83(90.2)$ & $9(9.8)$ & & \\
\hline Total & $261(87.0)$ & $39(13.0)$ & & \\
\hline \multicolumn{5}{|c|}{ Age group (years) } \\
\hline$<20$ & $10(100)$ & 0 & 9.8331 & $0.0073 * *$ \\
\hline $20-34$ & $184(90.2)$ & $20(9.8)$ & & \\
\hline $35-50$ & $58(79.5)$ & $15(20.5)$ & & \\
\hline$>50$ & $9(69.2)$ & $4(30.8)$ & & \\
\hline Total & $261(87.0)$ & 39 (13.0) & & \\
\hline
\end{tabular}


Table 3: Prevalence of occult B infection (OBI)with respect to gender and age groups of donors

\begin{tabular}{rccc}
\hline $\begin{array}{c}\text { Socio-demographic } \\
\text { characteristics }\end{array}$ & $\begin{array}{c}\text { HBV DNA negative } \\
\mathbf{n}(\mathbf{\%})\end{array}$ & HBV DNA positive & $\mathbf{n}$ \\
\hline Gender & Male & $56(96.6)$ & $2(3.4)$ \\
Female & $16(94.1)$ & $1(5.9)$ \\
Total & $\mathbf{7 2 ( 9 6 . 0 )}$ & $\mathbf{3}(\mathbf{4 . 0 )})$ \\
Age group (years) & $1(100)$ & 0 \\
$<20$ & $38(95.0)$ & $2(5.0)$ \\
$20-34$ & $27(96.4)$ & $1(3.6)$ \\
$35-50$ & $6(100)$ & 0 \\
$>50$ & $\mathbf{7 2 ( 9 6 . 0 )}$ & $\mathbf{3 ( 4 . 0 )}$ \\
\hline
\end{tabular}

Table 4: Summary of the results of the three cases of occult hepatitis B infections

\begin{tabular}{ccccc}
\hline Number sample & Gender & Age (years) & Donor type & Viral load (UI/mL) \\
\hline 11190226100 & Male & 35 & Occasional & \\
11190228800 & Male & 38 & Occasional & 26454 \\
11190225140 & Female & 26 & Occasional & 337
\end{tabular}

\section{Discussion:}

Among the 300 donors who made up the study population, males represented $69.3 \%$ compared to $30.7 \%$ females, with a male to female ratio of 2.3, similar to that reported by Yooda et al (8) of 2.47 in 2017 among blood donors in Ouagadougou. This can be explained by the much greater willingness of males to donate blood, unlike females where there are situations in which blood donation may be relatively contraindicated, such as pregnancy, menstruation, childbirth, and breastfeeding. The age group 20-34 year constituted the majority in the study, similar to the studies of Doumbia et al., (14) in 2015 in Burkina Faso and Oluyinka et al., (15) in 2015 among blood donors in Nigeria. This finding could probably be linked to the dynamism and ability of the young population to donate blood. It is all fairer to say that the best blood donors in Burkina Faso are pupils and students (8).

The prevalence of anti-HBc antibody of $13 \%$ in this study is lower than the rate of $18.4 \%$ reported by Yooda et al., (8) in 2017 and $44.0 \%$ by Somda et al., (11) in 2016 among blood donors in Burkina Faso. How- ever, it is higher than the $7.8 \%$ rate reported among blood donors in Egypt by Antar et al., (16) in 2010. The difference in rates reported may be due to the variations in sample size and study population, type of methods used, countries of study and the levels of HBV endemicity. Carriage of the anti HBc antibody is associated with the age of the study population. The age group over 50 years were most positive $(30.8 \%)$ for anti-HBC antibody in our study. Burkina Faso is one of the areas of high endemicity of the hepatitis B virus, and very often, the infection is contracted early in childhood and develops in a latent fashion. Chronic active HBV infection usually occurs late and may progress to cirrhosis or primary liver cancer.

In the present study, we recorded a prevalence of $4 \%$ for occult HBV infection, which may be linked to the endemicity of HBV in Burkina Faso. This rate is lower than $7.3 \%$ reported in Ouagadougou by Birama et al., (10) in 2018 and $32.8 \%$ reported among blood donors in Burkina Faso by Somda et al., in 2016 (11). On the other hand, this prevalence rate is closely related to $4.72 \%$ reported among blood donors in Ouagadougou by Yooda et al., (8) in 2017 but higher 
than $0.56 \%$ and $2.86 \%$ rates reported among blood donors respectively in Cameroon by Fopa et al., in 2019 (17) and in China by Ye et al., in 2017 (18). Although, several studies have shown that OBI depends on the endemicity of HBV, it is not limited to only countries with high HBV endemicity (10). The quality of the sample tested (blood or liver tissue) as well as the risks of contamination can also affect the detection of OBI (19).

In our study, donors with HBV DNA had viral load greater than $200 \mathrm{IU} / \mathrm{ml}$ (337$26,454 \mathrm{IU} / \mathrm{ml})$. In 2008 , the expert meeting clarified the definition of OBI by establishing cut-off value for serum HBV DNA $<200 \mathrm{IU} / \mathrm{ml}$ (20). In addition, it also clarified the confusion between overt HBV infection and "false" OBI. Thus, cases where viral loads are comparable to stages of overt HBV infection are usually due to infection with escape mutants and should be labeled as "false" OBIs (20), because these cases are in fact overt chronic hepatitis $B$. This is attributed to escape mutations that could have altered the target epitope of the HBsAg test (21). We believe that disregarding these definitions may contribute to overestimation of the prevalence of OBI.

In the present study, the viral loads being greater than $200 \mathrm{IU} / \mathrm{ml}$, is in favor of "false" OBIs. Of the 3 donors positive for HBV DNA, two were HBV anti-HBc antibody positive while one was negative. The two donors with positive anti-HBc antibody are considered as cases of occult B seropositive OBI while the one negative donor is considered a seronegative OBI, which is an indication of a recent $\mathrm{HBV}$ infection not detectable by the test method used.

\section{Conclusion:}

Occult HBV infection remains a big concern in Burkina Faso, as demonstrated by our current study and several other studies. Given the prevalence of OBI of $4 \%$ in this study and the consequences in blood recipients, it appears necessary that in addition to the detection of classic serological markers of hepatitis $B$, the presence of HBV DNA among blood donors should be tested, in order to ensure better transfusion safety.

\section{References:}

1. WHO. Disponible sur: https://apps.who.int/iris/ bitstream/handle/10665/232529/WER7928_255-263 [cité 16 Jul 2019]

2. Hepatitis WHO Regional Office for Africa. https://www.afro.who.int/health-topics/hepatitis accessed:29Jul2019

3. Lingani, $M$, Akita, T , Ouoba, $S$, et al. High prevalence of hepatitis $B$ infections in Burkina Faso (1996-2017): a systematic review with meta-analysis of epidemiological studies. BMC Public Health. 2019; 18. https://www. ncbi.nlm. nih.gov/pmc/articles/PMC5921387/

4. Simpore, J., Savadogo, A., Ilboudo, D., et al. Toxoplasma gondii, HCV, and HBV seroprevalence and co-infection among HIV-positive and -negative pregnant women in Burkina Faso. J Med Virol. $2006 ; 78$ (6):730-733.

5. Pietra, V., Kiema, D., Sorgho, D., Puoti, M., and Simpore, J. Prévalence des marqueurs du virus de I'hépatite $B$ et des anticorps contre le virus de I'hépatite $C$ parmi le personnel du District Sanitaire de Nanoro, Burkina Faso. 2008; 31 (1): $1-15$

6. Tao, I., Compaoré, T. R., Diarra, B., et al. Seroepidemiology of Hepatitis B and C Viruses in the General Population of Burkina Faso. Hepat Res Treat. 2014; 2014: 1-5.

7. Sanou, A. M., Benkirane, K., Tinto, B., et al. Prevalence of Hepatitis B virus and Hepatitis D virus Coinfection in Western Burkina Faso and molecular characterization of the detected virus strains. Int J Infect Dis 2018; 70: 15-19.

8. Yooda, A. P., Soubeiga, S. T., Nebie, K. Y., et al. Impact of Multiplex PCR in Reducing the Risk of Residual Transfusion-Transmitted Human Immunodeficiency and Hepatitis B and C Viruses in Burkina Faso. Mediterr J Hematol Infect Dis. 2018; 10 (1): 1-9

9. Healthcote, J. Abbas, Z., Alberti, A., et al. WGO Guideline. Hépatite B. 2008: 31

10. Yonli, A. T. Problematique de I'hepatite virale B au Burkina Faso: Prévalence, caractéristiques moléculaires des hepatites B chroniques et role des genes GSTM1 et GSTT1 dans la survenue du carcinome Hépatocellulaire. 2019.

11. Somda, K. S., Sermé, A. K., Coulibaly, A., et al. Hepatitis B Surface Antigen Should Not Be the Only Sought Marker to Distinguish Blood Donors towards Hepatitis B Virus Infection in High Prevalence Area. Open J Gastroenterol. 2016; 06: 362-372

12. Vivekanandan, P., Kannangai, R., Ray, S. C., Thomas, D. L., and Torbenson, M. Comprehensive genetic and epigenetic analysis of occult hepatitis $B$ from liver tissue samples. Clin Infect Dis. $2008 ; 46$ (8): 1227-1236.

13. Khattab, E., Chemin, I., Vuillermoz, I., et al. Analysis of HCV co-infection with occult hepatitis $B$ virus in patients undergoing IFN therapy. J Clin Virol. 2005; 33 (2): 150-157.

14. Doumbia, B. Caractérisation de l'infection occulte au virus Caractérisation de l'infection occulte au virus de I'hépatite $B$ dans la population de Ouagadougou, I'hepatite B dans la population de Ouagadougou, Mémoire Pour Iobtention du Master II de Biologie Moléculaire et de Genétique Moléculaire Appliquées de I'Université Ouaga 1 Pr. Joseph KI ZERBO

15. Oluyinka, O. O., Tong, H. V., Bui Tien, S., et al. Occult Hepatitis B Virus Infection in Nigerian Blood Donors and Hepatitis B Virus Transmission Risks. PLoS One. 2015; 10 (7): 1-13

16. Antar, W., El-Shokry, M. H., Abd El Hamid, W. $A$, and Helmy, M. F. Significance of detecting anti-HBC (6) negative for $\mathrm{HBsAg}$. Transfus Fopa, D., Candotti, D., Tagny, C. T., et al. Occult hepatitis B infection among blood donors from Yaoundé, Cameroon. Blood Transfus Sangue. 2019; 17 (6): 403-408.

18. Ye, X., Li, T., Xu, X., et al. Characterisation and follow-up study of occult hepatitis $B$ virus infection in anti-HBC-positive qualified blood donors in sou ( China. Blood

19. Zhu, H. L., Li, X., Li, J., and Zhang, Z. H. Genetic variation of occult hepatitis $B$ virus infection. World $]$ Gastroenterol. 2016; 22 (13): 3531-3546.

20. Raimondo, G., Allain, J. P., Brunetto, M. R., et al. Statements from the Taormina expert meeting on occult hepatitis B virus infection. J Hepatol. 2008; 49 (4): 652 - 657.

21. Bremer, C. M., Saniewski, M., Wend, U. C., et al. Transient occult hepatitis B virus infection in a blood donor with high viremia. Transfusion (Paris). 2009; 49 (8): 1621-1629. 